\title{
STRATEGI KOMUNIKASI DINAS PARIWISATA PROVINSI RIAU DALAM MENGIMPLEMENTASIKAN CHSE DI KOTA PEKANBARU
}

\section{Adrian Eko Desrilianto, Noor Efni Salam, Zulkarnain}

Pasca Sarjana Program Studi Ilmu Komunikasi Universitas Riau, Pekanbaru, Indonesia

Email: arya84.ripos@gmail.com, noor.efni.salam@lecturer.unri.ac.id, zulnuzula@gmail.com

\begin{abstract}
Abstrak
Penelitian ini bertujuan untuk mengetahui strategi komunikasi pada Dinas Pariwisata Provinsi Riau dalam mengimplementasikan CHSE di Kota Pekanbaru guna meningkatkan kunjungan wisatawan. Seluruh wewenang masih berada dipusat dan hanya diberikan pemberitahuan kepada pemerintah daerah dalam hal ini Dinas Pariwisata Provinsi Riau. Metode yang akan digunakan dalam penelitian ini dengan metode deskriptif kualitatif dengan pendekatan kostruktif dengan cara analisis data deskriptif yang akan digunakan untuk memehami situasi dan fenomena sosial pada manusiaa dan lingkungan sekitarnya. Hasil dari penelitian ini, Dinas Pariwisata Provinsi Riau sudah menerapkan strategi komunikasi dengan tahapan yang pasti. Komunikator yang dipilih untuk menyampaikan pesan komunikasi ditunjuk berdasarkan kredibilitasnya. Untuk komunikator internal adalah Kepala Dinas Pariwisata Provinsi Riau, Kepala Bidang Pengembangan Sumbedaya Pariwisata, Staf bidang promosi. Selain itu, komunikator yang berlabel public figure sebagai komunikator ekternal. Pesan yang disampaikan terkait penerapan CHSE juga dikemas dalam pesan yang menarik dan informatif sehingga dapat menjadi daya tarik serta menimbulkan kepercayaan publik dan rasa aman untuk mengunjungi tempat wisata di Pekanbaru dimasa pandemi Covid-19 ini. Jaminan kesehatan yang menjadi dasar dari penerapan CHSE dipaparkan dalam strategi komunikasi yang dilakukan melalui saluran komunikasi tradisional maupun media baru yaitu platform Instagram@pariwisata.riau dan youtube @pariwisata.riau serta melalui portal berita online, komunikasi publik media cetak, baliho dan spanduk.
\end{abstract}

Kata Kunci: strategi komunikasi; implementasi CHSE; tingkat kunjungan; dinas pariwisata provinsi riau; kota pekanbaru

\section{Abstract}

This study aims to determine the communication strategy at the Riau Province Tourism Office in implementing CHSE in Pekanbaru City in order to increase tourist visits. All authority is still in the center and only given notification to the local government in this case the Riau Province Tourism Office. The method that will be used in this research is descriptive qualitative method with a constructive approach by means of descriptive data analysis that will be used to understand situations and social phenomena in humans and the surrounding environment. The results of this study, the Riau Province Tourism Office has

$\begin{array}{ll}\text { How to cite: } & \text { Desrilianto. A. E (2021) Strategi Komunikasi Dinas Pariwisata Provinsi Riau dalam Mengimplementasikan } \\ & \text { CHSE di Kota Pekanbaru, Syntax Literate: Jurnal Ilmiah Indonesia 6(2) } \\ \text { E-ISSN: } & \text { 2548-1398 } \\ \text { Published by: } & \text { Ridwan Institute }\end{array}$


implemented a communication strategy with definite stages. The communicators selected to deliver the communication message are appointed based on their credibility. For internal communicators are the Head of the Riau Province Tourism Office, the Head of the Development of Tourism Resources, and the Promotional Staff. In addition, communicators labeled as public figures are external communicators. The message conveyed regarding the implementation of CHSE is also packaged in an interesting and informative message so that it can be an attraction and create public trust and a sense of security to visit tourist attractions in Pekanbaru during the Covid-19 pandemic. Health insurance which is the basis of the implementation of CHSE is described in a communication strategy carried out through traditional communication channels and new media, namely the Instagram @ pariwisata.riau and youtube @ pariwisata.riau platforms as well as through online news portals, print media public communications, billboards and banners.

Keywords: communication strategy; CHSE implementation; visitation rate; riau province tourism office; pekanbaru city

Received: 2021-10-20; Accepted: 2021-11-05; Published: 2021-11-20

\section{Pendahuluan}

Penyebaran corona virus pada akhir 2019 di Wuhan telah menyebabkan pandemi yang menjadi masalah dunia, termasuk Indonesia. Saat pandemi Covid-19 semakin parah, pemerintah bahkan menerapkan kebijakan PSBB (pembatasan sosial berskala besar) sehingga berdampak pada sistem stay at home dan work from home (Nugraha, 2021). Dengan adanya himbauan untuk tetap di rumah dan bekerja maka mobilitas perjalanan masyarakat dibatasi, sehingga pada tahap ini dampak yang paling mudah diperkirakan adalah dampak penurunan jumlah wisatawan selama pandemi COVID-19 (Nugraha, 2021). Aturan tersebut berdampak besar pada penurunan jumlah wisatawan ke Provinsi Riau dimana estimasi penurunan jumlah kunjungan wisatawan berdasarkan statistik pariwisata 2016-2020 ke Riau mencapai hingga 59,19\%.

Menurut Sumiyati dan Murdiyanto (2018) Jumlah Pengurangan jumlah wisatawan di tempat wisata ini disebabkan karena belum adanya strategi komunikasi yang tepat, seperti bagaimana merancang teknologi, mulai dari bagaimana merencanakan, melaksanakan, mengevaluasi, dan memantau pemanfaatan objek wisata dalam bauran komunikasi pemasaran yang digunakan untuk menarik wisatawan ke tempat wisata (marketing communication mix)

Pada akhirnya, di bulan Agustus 2020 Pemerintah pusat mengeluarkan kebijakan pembatasan sosial sesuai protokol kesehatan atau new normal melalui Peraturan Menteri Hukum dan HAM (PermenkumHAM) nomor 26/2020. Kawasan wisata alam di wilayah Provinsi Riau menjadi destinasi wisata pertama dibuka untuk umum secara bertahap (Berdasarkan SK Menteri LHK No. SK.261/MENLHK/KSDAE/KSA.0/6/2020). Langkah tersebut dibarengi dengan memberikan informasi protokol kesehatan bagi pekerja kreatif pada tanggal 28 Agustus 2020. 
Selanjutnya, Kementerian Pariwisata dan Ekonomi Kreatif (Kemenparkraf) juga mengeluarkan kebijakan CHSE (cleanliness, health, safety, environment sustainability) yang tertera dalam Permenparkraf nomor 13/2020 tentang standarisasi dan sertifikasi kesehatan, keselamatan dan kelestarian lingkungan sektor pariwisata dalam penanganan pandemi corona virus disease 2019. Hal tersebut menjadi standar baru dalam industri parawisata untuk melanjutkan keberlangsungan usaha atau destinasi wisata (Kemenparekraf, 2020).

Melalui Bidang Pengembangan Sumberdaya Pariwisata, Dinas Pariwisata Riau menyusun strategi guna meningkatkan kunjungan wisatawan ke tempat wisata di seluruh kabupaten/kota di Provinsi Riau. Mulai dari sosialisasi langsung turun ke DTW, kelompok sadar wisata hingga kampanye CHSE melalui beberapa media komunikasi. Tidak hanya itu, Dinas Pariwisata Riau juga telah melakukan sosialisasi kepada pelaku sektor pariwisata yang ada di 12 kabupaten/kota di Riau yang melibatkan 1.896 peserta dalam pemberian materi dan konsep terkait CHSE.

Strategi komunikasi adalah suatu rancangan (planning) dalam memanfaatkan serta mengkombinasikan panduan dari perencanaan komunikasi yang bertujuan untuk memperoleh atau menccapaai tujuan yang diinginkan. Maka dalam hal ini, terlihat adanya fenomena yang terjadi dalam strategi komunikasi Dinas Pariwisata Provinsi Riau pada penerapan CHSE. Berdasarkan sejumlah alasan dan latar berlakang tersebut diatas, peneliti ingin melihat bagaimana strategi komunikasi yang diterapkan Dispar Provinsi Riau dalam mengimplementasi CHSE di Kota Pekanbaru. Penelitian akan difokuskan pada strategi komunikasi yang dilakukan dalam menjalankan tugas pokok dan fungsi mempromosikan destinasi wisata kepada publik yang dalam hal ini yang dilakukan oleh Dinas Pariwisata Provinsi Riau pada kebijakan CHSE yang membuat kunjungan wisatawan meningkat.

\section{Metode Penelitian}

Penelitian ini mengunakan mtode penelitian kualitatif. Metode penelitian kualitatif ini lebih menekankan pada filsafat postpositivisme, yang digunakan biasanya pada kondisi objek yang alamiah (kebalikan dari eksperimen) (Sugiyono, 2017:15). Penelitian ini menggunakan pendekatan kostruktif dengan cara analisis data deskriptif yang akan digunakan untuk memehami situasi dan fenomena sosial pada manusia dan lingkungan sekitarnya, dimana peneliti memposisikan diri sebagai pengamat.

Jenis data ya g digunakan dalam penelitian ini adalah data kualitatif. Cara memperoleh data kualitatif dapat di lakukan melalui wawancara. Dalam penelitian ini dilakukan pengumpulan data dalam wujud data primer. Data Primer ialah jenis dan sumber data penelitian yang di peroleh secara langsung dari sumber pertama (tidak melalui perantara),baik individu maupun kelompok. Sumber data primer dalam penelitian ini berasal dari wawancaya yang dilakukan.

Informan sebagai sumber data primer yang dipilih di rencananakan, antara lain adalah: 
1. Kepala Dinas Pariwisata Provinsi Riau

2. Kepala Bidang Pengembangan Sumberdaya Pariwisata

3. Kepala Seksi Sarana Promosi / Kepala Seksi Promosi

4. Staf Seksi Promosi

5. Pelaku Usaha Pariwisata

Sementara sumber data skunder didapat dari dokumentasi dan obesrvasi.

Dokumentas dan observasi dilakukan seacra langsung di Kantor Dinas Pariwisata Provonsi Riau.

\section{Pembahasan}

1. Strategi memilih komunikator oleh Dinas Pariwisata Provinsi Riau mengimplementasikan CHSE untuk meningkatkan kunjungan wisata di Kota Pekanbaru

Salah satu unsur dalam strategi komunikasi adalah penentuan komunikator yang kredibel dan memiliki daya tarik serta kepercayaan khalayak. Hal ini sangat penting karena memiliki pengaruh pada tujuan dari strategi komunikasi yang diterapkan. Guna menarik kembali minat kunjungan wisatawan ke Kota Pekanbaru, Dinas Pariwisata menentukan komunikator baik internal maupun eksternal. Untuk pemilihan komunikator internal, Dinas Pariwista memanfaatkan Kepala Dinas dan Kepala Bidang Pengembangan Sumberdaya Pariwisata serta staf Dinas Pariwisata untuk langsung turun kelokasi dan melakukan dokumentasi untuk selanjutnya disebarkan terkait kebijakan dan tujuan CHSE ini. Pihak Dinas Pariwisata Provinsi Riau menempatkan mereka yang paham dan sengat mengerti serta dekat dengan pelaku usaha wisata agar dapat dengan jelas mengedukasi terkait kebijakan yang dikeluarkan oleh Kemenparkreaf di pertengahan tahun 2020 ini. Selain itu, Dinas Pariwisata Provinsi Riau juga menempatkan komunikator yang memiliki daya tarik khusus dalam komunikator ekternal. Komunikator yang berlabel public figure seperti artis Tyas Mirasih, Jennifer Arnelita, Budi Doremi, Dea Ananda dan Fahhil Achyari untuk menyampaikan bangkitnya pariwisata Riau seiring hadirnya kebijakan CHSE.

2. Strategi penentuan khalayak oleh Dinas Pariwisata Provinsi Riau untuk mengimplementasikan CHSE

Ditutupnya pintu masuk sebagian warga negara asing membuat wisatawan asing sulit masuk ke Provinsi Riau. Akibatnya, Dinas Pariwisata Provinsi Riau memiliki target khalayak hanya secara lokal. Untuk itu, sebagai komunikator harus benarbenar tepat memilih komunikator yang menjadi target dari strategi komunikasi untuk menarik minat wisatawan datang ke Riau. Dalam hal ini, Dinas Pariwisata membagi khalayak menjadi khalayak primer dan khlayak skunder.

Khalayak primer umumnya akan menjadi sasaran langsung dari mengimplementasikan CHSE ini. Mereka adalah target yang secara langsung mengikuti program-program yang dilakasanakan Dinas Pariwisata Provinsi Riau guna mengiatkan kembali pariwisata di Riau dan Pekanbaru khususnya. Dalam hal 
ini yang menjadi khalayak primer adalah pelaku usaha pariwisata, kelompokkelompok masyakat sadar wisata (Pokjadwis), komunitas kepemudaan hingga operator perjalanan wisata. Karena kecendrungannya berkelompok, memudahkan komunikator dalam menyampaikan tujuannya. Harapannya, mereka dapat secara langsung mengimplementasikan CHSE sesuai dengan aturan yang berlaku.

Sementara itu, khalayak skunder adalah masyarakat yang tidak terlibat secara langsung dalam program kebijakan CHSE namun mengetahui adanya kebijakan tersebut. Dalam hal ini, yang menjadi khalayak skunder adalah seluruh masyarakat Provinsi Riau maupun nusantara dimana akan mendapatan informasi melalui saluran komunikasi.

3. Strategi pesan yang disampaikan Dinas Pariwisata Provinsi Riau dalam mengimplementasikan CHSE

Pesan yang akan disampaikan kepada khalayak oleh komunikator menjadi sangat penting. Pasalnya, pesan yang terencana secara baik akan membuat khlayak tertarik untuk melakukan kegiatan wisata yang mengakibatkan meningkatnya kunjungan wisata. Dalam hal pengelolaan pesan, Dinas Pariwisata Provinsi Riau harus dapat memuculkan ketertarikan dan terbentuknya persepsi khalyak terhadap program CHSE yang berdampak pada kunjungan wisatawan.

Penekanan inti dari pesan yang diproduksi Dinas Pariwisata Provinsi Riau dibuat secara simpel dan mudah dimengerti oleh khalayak. Ini pesan yang disampaikan terdiri dari anjuran tetap protokol kesehatan hingga adanya jaminan tempat yang memiliki daya tarik wisata tersebut sudah menerapkan CHSE yang ditandai dengan sertifikat CHSE. Pesan tersebut membuat khlayak memiliki rasa ketertarikan untuk melakukan kunjungan wisata ke berbagai destinasi wisata di Kota Pekanbaru. Selanjutnya, untuk mempermudah atau membuat pesan mudah diingat dengan adanya hastag \#keriauaja dan \#wisatariaubedelau juga membuat pengelolaan pesan menjadi lebih efektif dan mudah dingat.

4. Strategi Saluran Komunikasi Yang Digunakan Dinas Pariwisata Provinsi Riau Dalam Mengimplementasikan CHSE

Media atau saluran komunikasi menjadi penting dimasa ini. Saluran komunikasi tidak hanya menjadi pendukung, tapi juga menjadi elemen penting untuk menentukan keberhasilan sebuah pesan dalam mencapai tujuan komunikasi. Saluran komunikasi juga merupakan upaya untuk menyampaikan pesan kepada khalayak sasaran oleh komunikator dalam bentuk pesan.

Ada banyak saluran komunikasi yang dapat dimanfaatkan dalam melakukan strategi komunikasi, seperti tatap muka langsung. Saluran komunikasi secara berkelompok dilakukan secara melalui perkumpulan komunitas maupun dilakukan sosialiasi secara masif ke pelaku wisata. Selain itu, Dinas Pariwisata Provinsi Riau dalam mengimplementasikan CHSE memilih saluran komunikasi memanfaatkan salurah komunikasi media luar ruangan melalui media cetak (surat kabar, spanduk, baleho) dan media baru (media sosial dan media online) seperti melaui platform Instagram @ pariwisata.riau dan youtube @ pariwisata.riau. 


\section{Kesimpulan}

Strategi komunikasi yang telah diterapkan oleh Dinas Pariwisata Provinsi Riau dalam mendorong pengimplementasian CHSE di bidang wisata melalui tatap muka serta informasi di kelompok khusus karena tidak ada delegasi yang jelas dari Kementrian Pariwisata dan Ekonomi Kreatif untuk pengimplementasian CHSE di daerah. Hasil dari penelitian ini, Dinas Pariwisata Provinsi Riau sudah menerapkan strategi komunikasi dengan tahapan yang pasti. Komunikator yang dipilih untuk menyampaikan pesan komunikasi ditunjuk berdasarkan kredibilitasnya. Untuk komunikator internal adalah Kepala Dinas Pariwisata Provinsi Riau, Kepala Bidang Pengembangan Sumbedaya Pariwisata, Staf bidang promosi. Selain itu, komunikator yang berlabel public figure seperti artis Tyas Mirasih, Jennifer Arnelita, Budi Doremi, Dea Ananda dan Fahhil Achyari yang merupakan pemenang The New L-Men Of The Year 2020 menjadi komunikator ekternal. Pesan yang disampaikan terkait penerapan CHSE juga dikemas dalam pesan yang menarik dan informatif sehingga dapat menjadi daya tarik serta menimbulkan kepercayaan publik dan rasa aman untuk mengunjungi tempat wisata di Pekanbaru dimasa pandemi Covid-19 ini. Jaminan kesehatan yang menjadi dasar dari penerapan CHSE dipaparkan dalam strategi komunikasi yang dilakukan melalui saluran komunikasi tradisional maupun media baru yaitu platform Instagram @ pariwisata.riau dan youtube@pariwisata.riau serta melalui portal berita online, komunikasi publik media cetak, baliho dan spanduk. 


\section{BIBLIOGRAPHY}

Cangara, H. (2013). Perencanaan dan strategi komunikasi. Jakarta: Raja Grafaindo Persada. Google Scholar

Effendy, Onong Uchjana. (2009). llmu komunikasi teori dan praktek. Bandung: Remaja Rosdakarya. Google Scholar

Fitriana, R., Simanjuntak, D., \& Dewanti, R. (2020). Pembekalan Materi CHSE (Cleanliness, Health, Safety and Environmental Sustainability) dalam Training of Trainers Akademisi Pendamping Desa Wisata. CARADDE: Jurnal Pengabdian Kepada Masyarakat, 3(1), 138-145. Google Scholar

Kemenkeraf. (2020). Pemberdayaan Masyarakat Desa Wisata Berbasis Pendampingan. Jakarta: Direktorat Pengembangan SDM Pariwisata Kementerian Pariwisata dan Ekonomi Kreatif. Google Scholar

Lumanauw, N. (2020). Edukasi Dan Implementasi Protokol Clean Health Safety Environtment Melalui We Love Bali Kemenparekfraf Pada Program 10 SanurNusa Penida-Nusa Lembongan-Sanur. Jurnal Ilmiah Hospitality Management, 11(1), 71-81. Google Scholar

Nugraha, Y. E. (2021). Dampak Pandemi Covid 19 Pada Unit Usaha Pariwisata di Kawasan Pesisir Kota Kupang. Jurnal Industri Pariwisata, 3(2), 134-149. Google Scholar

Sugiyono. (2017). Metode penelitian kuantitatif, kualitatif, dan R\&D. Bandung: Alfabeta. Google Scholar

Sumiyati, \& Murdiyanto, L. (2018). Strategi komunikasi pemasaran pariwisata untuk meningkatkan kunjungan wisatawan di pantai suwuk kabupetn kebumen. Jurnal Wacana, 17(2), 171-180. Google Scholar

\section{Copyright holder:}

Adrian Eko Desrilianto, Noor Efni Salam, Zulkarnain (2021)

First publication right:

Syntax Literate: Jurnal Ilmiah Indonesia

This article is licensed under:

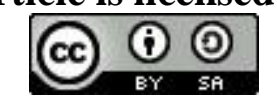

